\title{
Design, Development And Implementation Of A Smart And Economically Viable Solar Power Charge Controller.
}

\author{
${ }^{1}$ AMUDA F.A ${ }^{2}$ MUSTAPHA M. \\ 1,2 Electrical Engineering Department Hussaini Adamu Federal Polytechnic, Kazaure Jigawa State, Nigeria.
}

\begin{abstract}
A Smart and economically viable solar power charge controller has been design and implemented. The system was implemented using Arduino Microcontroller. The microcontroller was used in order to make the system smart, robust and simple. The system was tested under different atmospheric conditions. The result obtained shows that the developed charge controller performs efficiently. The system is also shown to be economically viable as the major component in its development is the Arduino microcontroller.
\end{abstract}

\section{INTRODUCTION.}

Electricity is one of the most essential needs for humans in the present. Conversion of solar energy into electricity does not only improve generation of electricity but also reduces pollution from fossil fuels. The output power of solar panel depends on solar irradiance, temperature and the load impedance. As the load impedance is dependent on application, a dc-dc converter is used for improving the performance of solar panel [12].

Solar PV is one of the renewable energy sources used in present days technology. PV has many benefits especially in environmental, economic and social aspects. In general, a PV system consists of a PV array which converts sunlight to direct-current electricity, a control system which regulates battery charging, and the load [12]

A charge controller is one of functional and reliable major components in PV systems. A good, solid and reliable PV charge controller is a key component of any PV battery charging. The main function of a charge controller in a PV system is to regulate the voltage and current from PV solar panels into a rechargeable battery. Solar charge controllers play an important part in isolated solar systems. The minimum function of a solar charge controller is to disconnect the array when the battery is fully charged and keep the battery fully charged without damage. This goal is to ensure the batteries are working in optimal conditions, mainly to prevent overcharging (i.e. by disconnecting solar panel when batteries are full) and too deep discharge (by disconnecting the load when necessary). It also offers protection against the reverse current flow at night back to the PV [14]

This research was implemented to overcome the challenges of previous works. It has the advantage of adding a microcontroller (ATMEGA328P-PU) chip, liquid crystal display (LCD) for readability of the voltage across the solar panel and, also the battery, this work operates during day and/ or night, it has the advantage of connecting DC load on the system, simple and economically viable.

\section{DESIGN AND IMPLEMENTATION}

In this section, we present the design of the solar charge controller. By knowing design specification and available input parameters, we can have an accurate and simple relationship between the input and output to perform the require task.

\section{DESIGN PROCEDURES}

The developed charge controller consists the following units:

1. Voltage sensing

2. PWM signal generation

3. MOSFET switching and driver

4. Filter and protection

5. Display and Indication

6. Software design

\section{VOLTAGE SENSORS}

The main sensor in the charge controller is voltage sensors which can easily be implemented by using a voltage divider circuit. We have to sense voltage coming from solar panel and the battery voltage. 

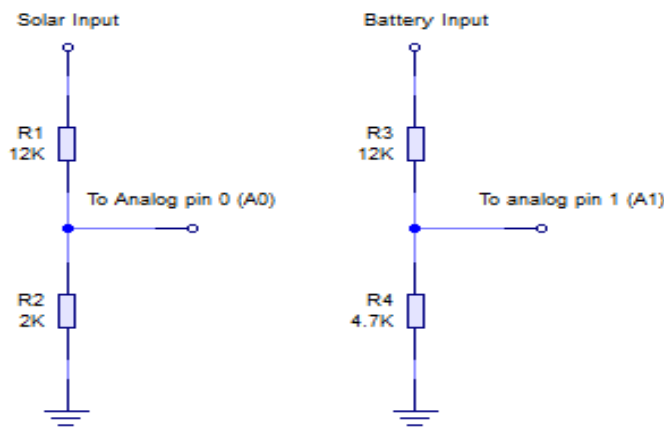

Figure 1 voltage sensor circuit

The charge controller was designed for a $6 \mathrm{~V}, 5 \mathrm{w}$ battery and, $16 \mathrm{~V}$ solar panel. Higher voltage values can be implemented by changing the divider resistors values.

\section{Software code}

ADC Calibration :

actual volt/divider output $=3.127$

$2.43 \mathrm{~V}$ is eqv to $520 \mathrm{ADC}$

1 is eqv to $.004673 \mathrm{~V}$

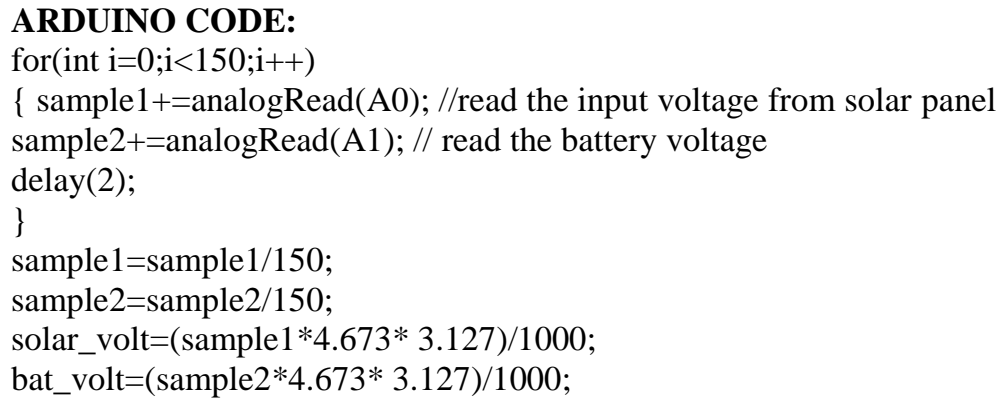

\section{PWM SIGNAL GENERATION}

PWM (pulse width modulation) is a technique that is simply used to control a digital output signal by switching it on and off very quickly, by varying the width of the on/off duration, it will give the effect of varying the output voltage [11].

Time period $(\mathrm{T})=$ Ton + Toff

$$
\text { Vout }=\frac{\text { Ton }}{(\text { Ton }+ \text { Toff })} \times \text { Vin }
$$

So Vout $=\frac{\text { Ton }}{\mathrm{T}} \times$ Vin

Where $\frac{\text { Ton }}{(\text { Ton }+ \text { Toff })} \times 100$ or $\frac{\text { Ton }}{T} \times 100$ is called Duty Cycle

\section{MOSFET SWITCHING AND DRIVER}

In this charge controller two MOSFETs where used in which one is for controlling the power flow from solar panel to battery and other is to drive the load. A gate driver is a power amplifier that accepts a lowpower input from a micro controller and produces a high-current drive input for the gate of a high-power MOSFET. 


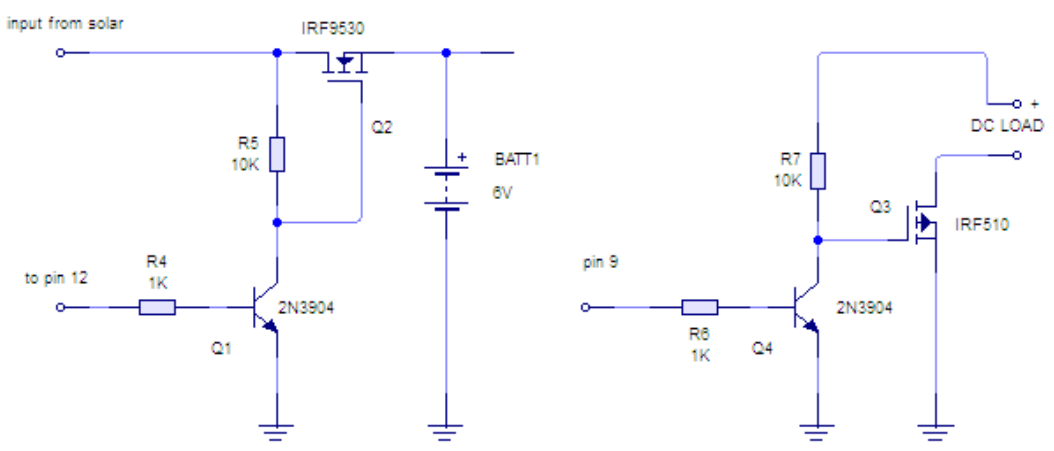

Figure 2: MOSFET driver circuit

This circuit is really important in this PV charge controller in order to amplify and translate the PWM signal from Arduinor microcontroller (ATMEGA328) to trigger POWER MOSFET (IRF9530 and IRF540 this MOSFET can withstand up to 100v) gate and the high output.

\section{Calculation of components values}

A resistor $R_{B}$ is connected to the base of the transistor to limit the maximum current through the base circuit to $4 \mathrm{~mA}$, and the value of $R_{B}$ was obtained as follows;

$\mathrm{V}_{\mathrm{BB}}-\mathrm{I}_{\mathrm{B}} \mathrm{R}_{\mathrm{B}}-\mathrm{V}_{\mathrm{BE}}=0$

$\mathrm{V}_{\mathrm{BB}}=+5 \mathrm{~V}$, (maximum input signal from microcontroller), $\mathrm{V}_{\mathrm{BE}}=0.7 \mathrm{~V}$

$5-\left(4 \times 10^{-3} \times \mathrm{R}_{\mathrm{B}}\right)-0.7=0$

$0.004 \mathrm{R}_{\mathrm{B}}=5-0.7=4.3$

$\mathrm{R}_{\mathrm{B}}=\frac{4.3}{0.004}=1070 \approx 1.07 \mathrm{~K} \Omega$

$\mathrm{R}_{\mathrm{B}}=1 \mathrm{~K} \Omega$ was used

In order to limit the maximum collector current $\left(\mathrm{I}_{\mathbf{c}}\right)$ to $1.2 \mathrm{~mA}$ when the output of the transistor is low, a pull up resistor is connected between $+12 \mathrm{~V}$ supply.

$\mathrm{V}_{\mathrm{CC}}-\mathrm{I}_{\mathrm{C}} \mathrm{R}_{\mathrm{C}}-\mathrm{V}_{\mathrm{CE}}=0$

$12-\mathrm{I}_{\mathrm{C}} \mathrm{R}_{\mathrm{C}}-0=0\left(\mathrm{~V}_{\mathrm{CE}}=0\right.$ at saturation $)$

$12-\left(1.2 \times 10^{-3} \times \mathrm{R}_{\mathrm{c}}\right)-0=0$

$12-\left(0.0012 \mathrm{R}_{\mathrm{c}}\right)=0$

$0.0012 \mathrm{R}_{\mathrm{c}}=12$

$\mathrm{R}_{\mathrm{c}}=\frac{12}{0.0012}=10000=10 \mathrm{~K} \Omega$ 


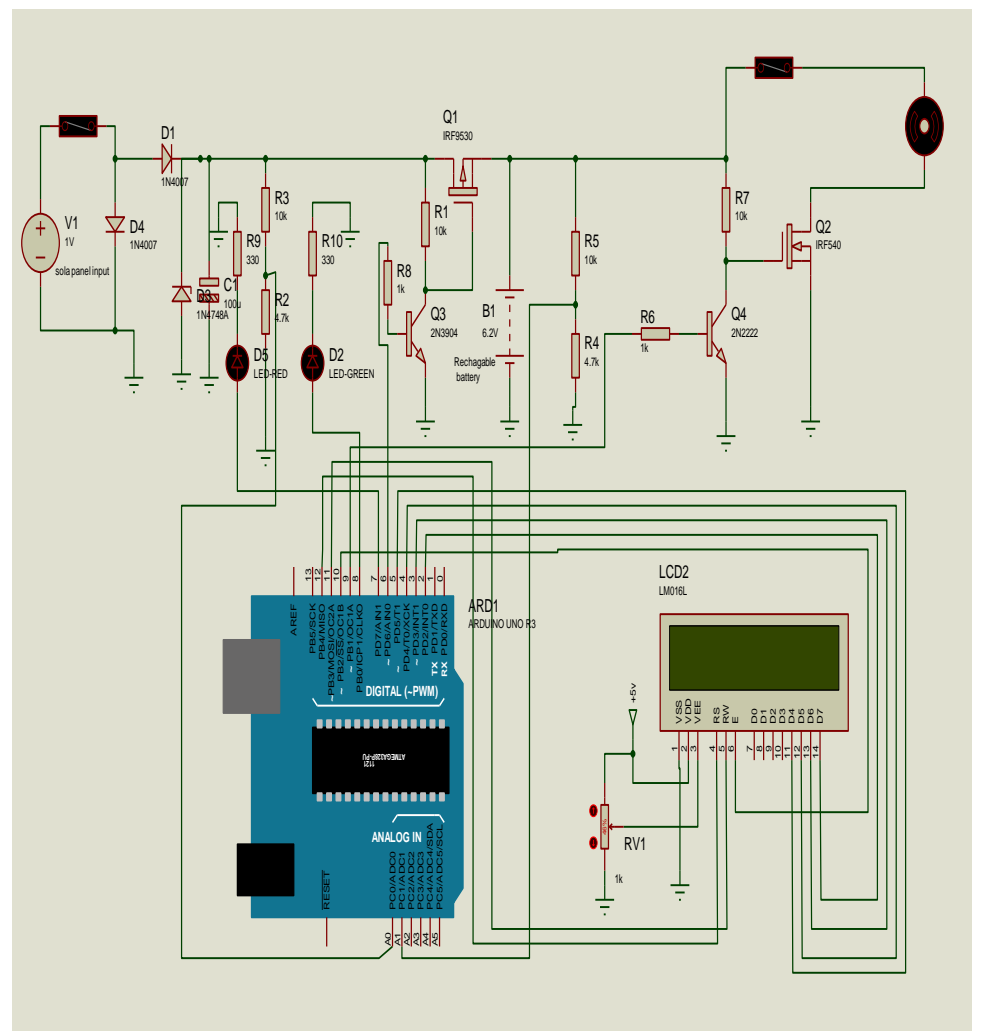

Figure3: Proteus Software Circuit Implementation

Oscilloscope was used to get the PWM output from the microcontroller. The PB5SACK pin generates square waves. Therefore, the 12th pin of the microcontroller was connected to the Channel A of the oscilloscope. The output of three different voltage of the battery cell is given thus.

\section{Not Charging:}

In the figure below it shows that the duty cycle of PWM is zero $(0 \%)$, which mean the battery is not charging from the solar panel this is because the voltage of the battery is below 6.0vor the voltage drown from the solar panel is less than the battery voltage.

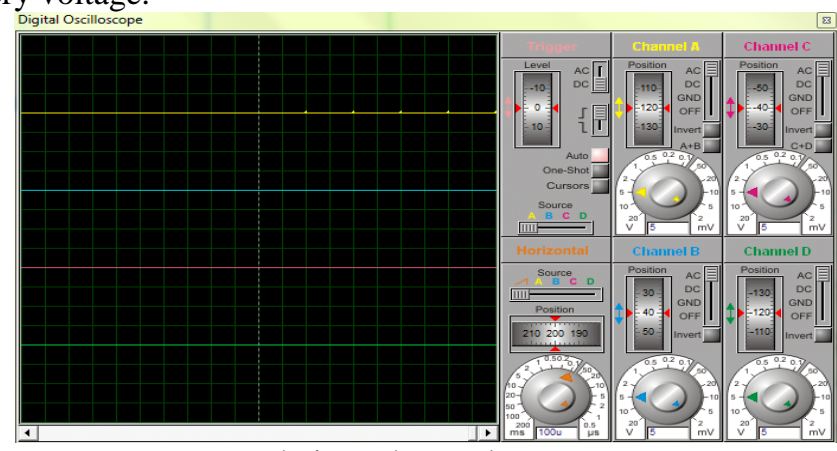

'Figure4: No charge

Float Charge: *

In this case the charging of the system is increasing between $6.2 \mathrm{~V}$ to $7.0 \mathrm{~V}$ with duty cycle of $10 \%$ to $89 \%$. Below diagram shows PWM of $10 \%$ duty cycle 


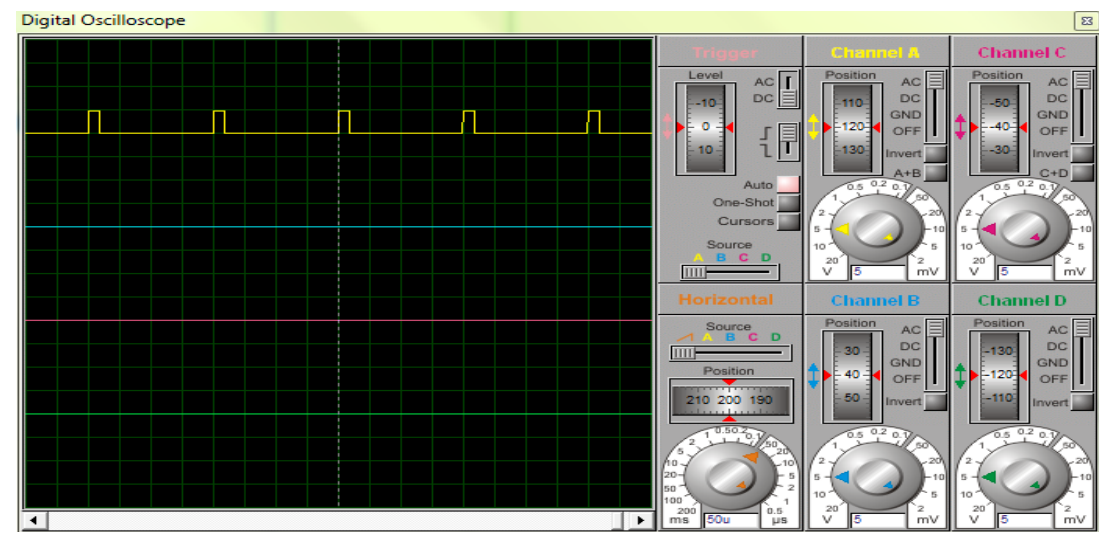

Figure5 $10 \%$ pulse width

Bulk Charge:

It is when voltage is between $7.1 \mathrm{~V}$ to $7.4 \mathrm{~V}$ of it fully charged. Duty cycle used: $90 \%$

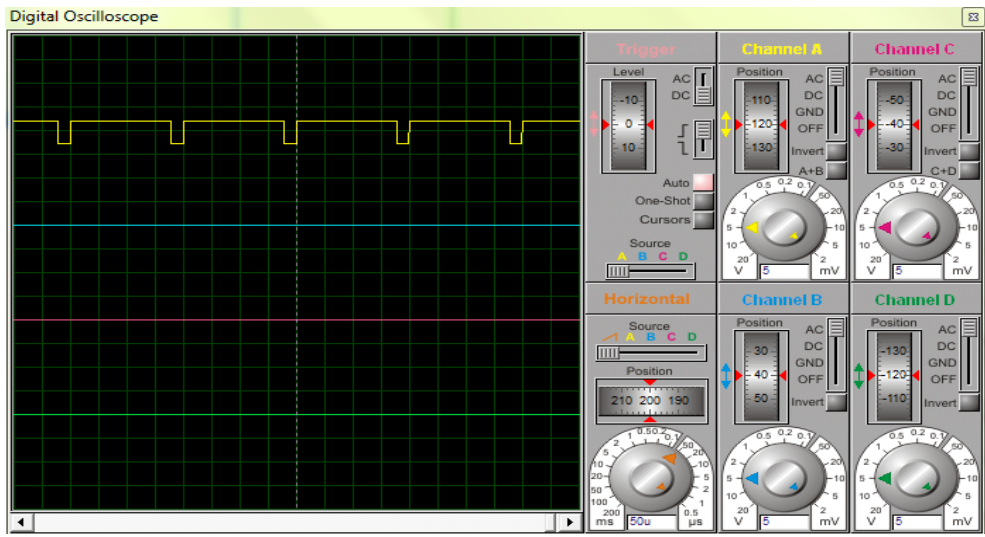

Figure $690 \%$ pulse width

\section{TESTING}

After the completion of the project, various test and measurements were carried out on the circuit to ascertain its workability. These include continuity test, short circuit and open circuit tests, dc voltage level tests; these were done using a digital multimeter.

The assurance of project work was determined by testing, which makes it necessary to test the circuit during and after construction. The main three test where carried out during the construction. These tests are stated below.

i. Temporary test

ii. Permanent test

iii. Final Test after casing

Temporary Test

This is a type of test that is done by assembling the components on the testing board (braed-board) after software simulation to testify its working practically normal. Below is the typical picture of the assembled component in the bread board. 


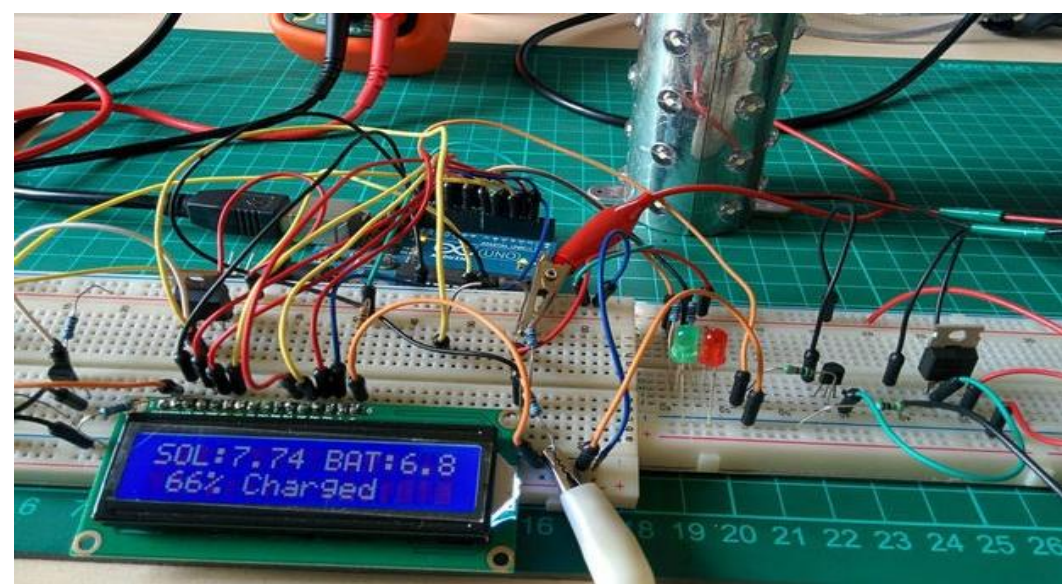

Figure.7 Diagram of Temporal Construction

\section{Permanent Test}

This is a kind of test that takes place after construction that is after fixing the components in the pin solder terminal of the permanent board ( vero board). The short circuit test, open circuit test and continuity test were carried out, so as to make sure the proper working of the circuit before the casing of the entire system, as it's pictorially shown below.

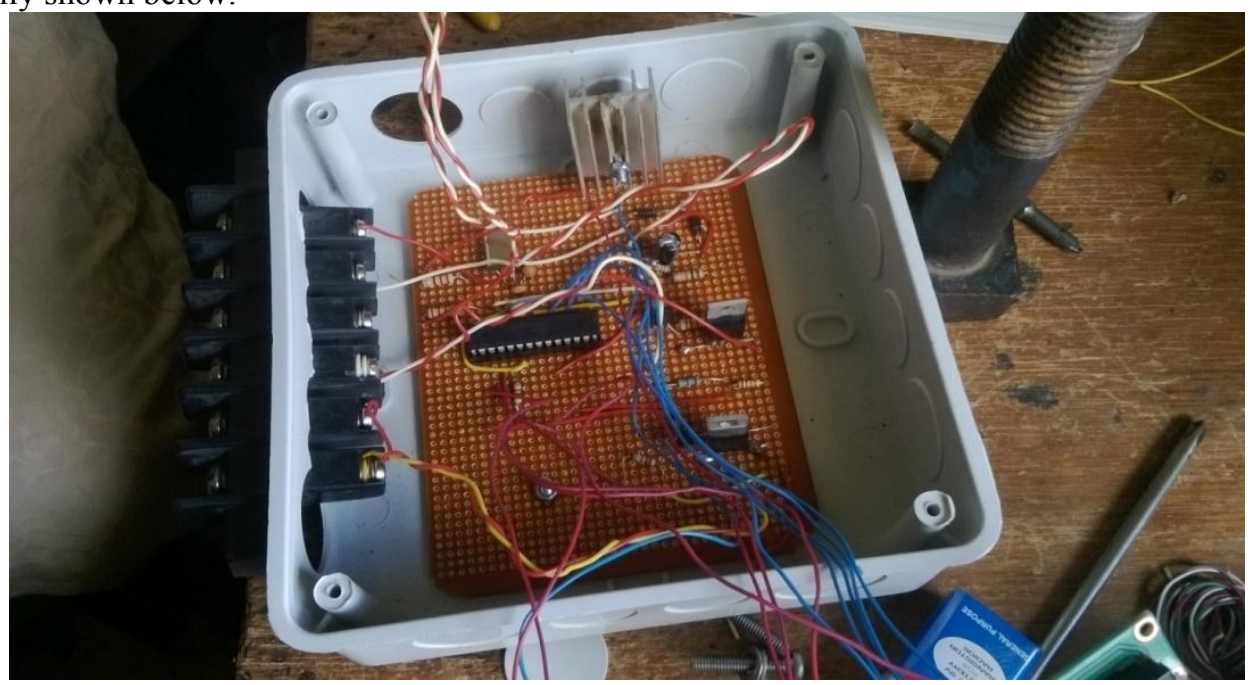

Figure8 Diagram of Permanent Construction

\section{Final Test after Casing}

The time taken to recharge any battery is dependent on the voltage and current applied to it. If the recharged current or voltage is too low, then the recharge time will be relatively long; if the current or voltage is high then the recharge time will be short. After construction and casing of project, the readings were taken using $12 \mathrm{~V} / 5 \mathrm{~W}$ solar panel and $6 \mathrm{~V} / 4.5 \mathrm{~h}$ lead-acid rechargeable battery. This test was carried out and the result was tabulated below (4.3).

VII. RESULTS

Table 4.1 Result Obtained

\begin{tabular}{|l|l|l|l|l|l|l|}
\hline s/n & Solar & Battery & PWM $\%$ & DC Load & Green LED & Read LED \\
\hline 1. & $10.28 \mathrm{~V}$ & $4.1 \mathrm{~V}$ & $\begin{array}{l}\text { Not } \\
\text { charging }\end{array}$ & ON & OFF & ON \\
\hline 2. & $10.26 \mathrm{~V}$ & $6.2 \mathrm{~V}$ & $16 \%$ & ON & Blinking & OFF \\
\hline 3. & $10.26 \mathrm{~V}$ & $6.3 \mathrm{~V}$ & $25 \%$ & ON & Blinking & OFF \\
\hline 4. & $10.38 \mathrm{~V}$ & $6.5 \mathrm{~V}$ & $41 \%$ & ON & Blinking & OFF \\
\hline 5. & $15.48 \mathrm{~V}$ & $6.8 \mathrm{~V}$ & $66 \%$ & ON & Blinking & OFF \\
\hline 6. & $15.13 \mathrm{~V}$ & $7.3 \mathrm{~V}$ & $83 \%$ & ON & Blinking & OFF \\
\hline 7. & $13.49 \mathrm{~V}$ & $7.4 \mathrm{~V}$ & $91 \%$ & ON & ON & OFF \\
\hline
\end{tabular}

The table above show the result of the test carried out after the completion of the entire work. In the table above it can be observed that the voltages supply from the solar panel increases from the first to the final reading, this is because of the intensity of the sun ray which is not constant. the percentage of the respective reading of the voltage drawn from the solar and battery level of charging voltages were indicated and the green LED is 
blinking showing that the battery is charging continuously, but red LED glows only when the voltage drawn from the solar panel is too low to charge the battery or if the charging battery is bad. Below is the pictorial diagram of the complete system under testing.

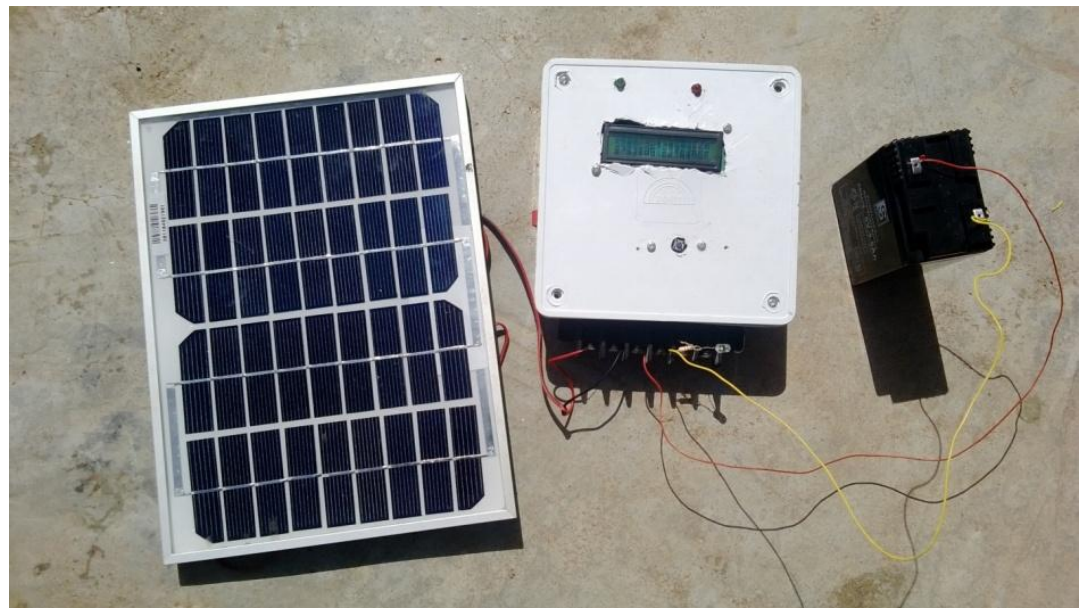

Figure.9 Pictorial Diagram of Complete Constructed Solar Charge Controller During Test.

VIII. DISCUSSION OF RESULTS

The reading taken from this test which is tabulated above was at random time, and It was observed that, the battery took much of time before it riches above $90 \%$ (i.e full charge mode) level and this is because of the current drown from the $5 \mathrm{~W}$ solar panel is very small and the test was conducted in cloudy day when there is no maximum sun light.

\section{REFERENCES}

[1] B.L. Theraja and A.K. Theraja (2005): "A text book of electrical Technology”. S. Chand \& Company Ltd, Ram Nagar, New Dehli. pp1116 - 1123

[2] Banzi, M. (2008, october 1). ATmega328. Retrieved april 22, 2013, from arduino: www.arduino.cc

[3] Ferdausi, M. (2010). "charge controller for solar charging station". BRAC University, Dhaka, Bangladesh

[4] J.B. Gupta (2009): "Electronics Devices and Circuits”. S.K. Kataria \& sons, Daryaganj Delhi. P78

[5] James P. Dunlop, P.E. et al, "Batteries and Charge Controller in Stand-Alone Photovoltaic Systems fundamentals and applications"

[6] KORENČIAK, P. (2011) "Charge controller for solar panel based charging of lead-acid batteries". Brno University of Technology, Faculty of Electrical Engineering and Communication,

[7] R. M. Dell, David Anthony James Rand, Understanding Batteries (Royal Society of Chemistry, 2001)

[8] R.L. Boylestad and L. Nashelsky (1996). "Electronic Devices and Circuit Theory", Prentice Hall, seventh edition, London, pages 46-52.

[9] Sciencedaily "World record solar cell with 44.7\% efficiency" sciencedaily. Retrieved 2014-10-12

[10] Woodworth, Joseph (1994), 'Evaluation of the Batteries and Charge Controllers in Small Stand-Alone Photovoltaic Systems.' Sandia National Laboratory.

[11] Pariyanka P, Rakesh K.J,(2016). Design and development of charge controller for 5kw wind Turbine. International Journal of Science Technology Management and Research vol1, issue3.

[12] Mara K, Michele L.C.(2016) A Review of current energy systems and green energy potential in Kazakhstan. Renewable and sustainable energy review Vol55 pg 491-504.

[13] Atiqur M,R, Matin M.A, Apurba S, Rubaiat U (2015). A Cost Effective Solar charger control. Journal of Engineering and Technology vol 14

[14] Sakib B.A, Shaika LI, Tanvina Z,K. Nuzhat N.M.(2016) prospect and constraints of Renewable Energy Sesctor in Bangladesh: An Analytical Exercise. World Journal of Social Science. Vol 16 PP1-12.

[15] Ramachanda T.V, RishabhJ, Ganthan K.(2011).Hotsports of Solar potential in India. Renewable and sustainable Energy Review.

[16] AkinboroF,g; Adejumobi L.A Makinde V (2012) Solar Energy Installation in Nigeria: Observations, Prospect, Problems and solution. Translational journal of Science and Technology Vol 2 No 4. 